\title{
PENYIMPANGAN PRINSIP KESANTUNAN PADA TEKS PENGUMUMAN KARYA SISWA KELAS VII SMP MUHAMMADIYAH 4 SAMBI TAHUN AJARAN 2015/2016:TINJAUAN PRAGMATIK
}

\author{
Wahyu Hartiningrum dan Yunus Sulistyono \\ Program Studi Bahasa Indonesia \\ Fakultas Keguruan dan Ilmu Pendidikan \\ Universitas Muhammadiyah Surakarta \\ J1. A. Yani Tromol Pos 1 Pabelan Kartosuro, Surakarta (57127) \\ Email: wahyuhartiningrum@gmail.com \\ As193@ums.ac.id
}

\begin{abstract}
ABSTRAK
Penelitian ini bertujuan:(1) Mengidentifikasi bentuk-bentuk penyimpangan kesantunan berbahasa dalam teks pengumuman karya siswa kelas VII SMP Muhammadiyah 4 Sambi dan (2) Menjabarkan bentuk kesantunan yang benar terhadap penyimpangan kesantunan berbahasa dalam teks pengumuman karya siswa kelas VII SMP Muhammadiyah 4 Sambi. Jenis penelitian ini adalah penelitian kualitatif. Objek yang ada pada penelitian ini adalah penyimpangan kesantunan berbahasa pada teks pengumuman hasil karya siswa kelas VII. Data penelitian ini berupa kata dan kalimat yang mengandung penyimpangan kesantunan berbahasa pada teks pengumuman hasil karya siswa kelas VII SMP Muhammadiyah 4 Sambi. Sumber data penelitian ini diambil dari teks pengumuman hasil karya siswa kelas VII SMP Muhammadiyah 4 Sambi. Teknik pengumpulan data di antaranya metode simak dan catat, rekam dan dokumentasi. Teknik keabsahan data dalam penelitian ini menggunakan teknik triangulasi. Teknik analisis data menggunakan metode padan intralingual. Hasil penelitian ini menunjukkan bahwa bentuk ketidaksantunan berbahasa pada teks pengumuman karya siswa kelas VII SMP Muhammadiyah 4 Sambi Boyolali, meliputi cost-benefit scale atau skala kerugian dan keuntungan, optionality scale atau skala pilihan, indirecness scale atau skala ketidaklangsungan, authority scale atau skala keotoritasan, dan social distance atau skala jarak sosial. Ketidaksantunan berbahasa dalam teks pengumuman karya siswa ditinjau dari skala kerugian dan keuntungan berjumlah dua data. Ketidaksantunan berbahasa dalam teks pengumuman karya siswa ditinjau dari skala ketidaklangsungan berjumlah tujuh data. Ketidaksantunan berbahasa dalam teks pengumuman karya siswa ditinjau dari skala pilihan berjumlah tiga belas data. Ketidaksantunan berbahasa dalam teks pengumuman karya siswa ditinjau dari skala keotoritasan berjumlah satu data.
\end{abstract}

Kata kunci: penyimpangan kesantunan, teks pengumuman

\section{ABSTRACT}

This research has two aims as follow (1) to identify forms of deviation linguistic politeness in the text of announcements made by students of class VII SMP Muhammadiyah 4 Sambi (2) to describe the correct form of politeness to deviations linguistic politeness in the text of announcement made by students of VII grade SMP Muhammadiyah 4 Sambi. This research is a qualitative research. Objects of this research is a deviation politeness on the text of announcement made by students of VII grade. This research data such as words and sentences that contain the 
deviation politeness on the text of announcement made by students of VII grade SMP Muhammadiyah 4 Sambi. Data collection techniques are observe attentively methods and take notes, record and documentation. Authenticity technique of data in this research use triangulation technique. Data analysis techniques use padan intralingual method. This research results indicate that form of impoliteness speaking at announcement text made by students of VII grade SMP Muhammadiyah 4 Sambi Boyolali, include cost-benefit scale or of losses and gains scale, optionality scale, indirecness scale, authority scale, dan social distance. Impoliteness speaking on the text of announcement made by students in terms of optionality scale amounts to thirteen data. Impoliteness speaking on the text of announcement made by students in terms form authority scale amounts to one data

\section{Keywords: impoliteness, announcement texts, SMP students}

\section{PENDAHULUAN}

Perkembangan kebahasaan memunculkan adanya ilmu bahasa, yaitu mengenai bidang studi pragmatik. Pragmatik merupakan ilmu yang semakin banyak dikembangkan pada bidang kebahasaan sehingga banyak linguis yang membahas tentang studi pragmatik. Leech (dalam Rahardi, 2010:48) menyatakan bahwa fonologi, sintakisis, dan semantik merupakan bagian tata bahasa atau gramatika, sedangkan pragmatik merupakan bagian dari penggunaan bahasa (language use). Pragmatik dapat berintegrasi dengan tata bahasa atau gramatika yang meliputi fonologi, morfologi, dan sintaksis melalui semantik.

Bahasa Indonesia merupakan mata pelajaran yang wajib dipelajari oleh semua sekolah dengan tingkat kesulitan sesuai jenjang kelas yang sedang ditempuh. Mata pelajaran bahasa Indonesia terdiri dari beberapa Standar Kompetensi dan Kompetensi Dasar. Salah satu Kompetensi Dasar yang diberlakukan pada kelas VII semester 1 (Gasal), yaitu tentang (4) Mengungkapkan pikiran dan pengalaman dalam buku harian dan surat pribadi dengan Kompetensi Dasar (4.3) Menulis teks pengumuman dengan bahasa yang efektif, baik, dan benar.

Salah satu indikator mencapaian kompetensi yang harus ditempuh siswa kelas VII yaitu mampu menulis teks pengumuman dengan bahasa yang efektif. Siswa diharapkan dapat menulis teks pengumuman menggunakan bahasa yang baik, santun, serta sesuai ejaan yang disempurnakan. Namun, dilihat dari kemampuan siswa kelas VII SMP Muhammadiyah 4 Sambi, belum bisa menerapkan kesantunan berbahasa dalam proses pembelajaran.

Santun berarti: (1) halus dan baik (budi bahasanya, tingkah lakunya) sabar dan tenang, sopan; (2) penuh rasa belas kasihan, suka menolong. Adapun sopan adalah: (1) hormat dan takzim (akan, kepada) tertib menurut adat yang baik; (2) beradab tentang tingkah laku, tutur kata, pakaian, dan sebagainya; 3) baik kelakuannya (tidak lacur, tidak cabul) (KBBI dalam Markhamah, 2013:117). Kesantunan berbahasa berarti berusaha menggunakan bahasa dengan baik, halus, dan sopan.

Berbicara sebagai salah satu keterampilan berbahasa juga memerlukan kesantunan. Hal ini menandakan bahwa seseorang harus benar-benar memikirkan kata-kata yang tepat untuk menyampaikan sesuatu (berbicara), serta dampaknya terhadap pendengar. Seseorang tentu harus mengetahui aspek-aspek penting untuk mewujudkan kesantunan berbahasa dalam berbicara. Salah satunya adalah dengan menerapkan prinsip kesantunan atau biasa juga disebut prinsip kesopanan.

Penelitian yang dilakukan oleh Budi Setiawan (2011) yaitu "Realisasi Ketidaksantunan Berbahasa di Lingkungan Terminal Kartasura". Hasil penelitian ini meyimpulkan bahwa 
ketidaksantunan berbahasa di lingkungan terminal menunjukkan bahwa tuturan para calo, pedagang asongan, sopir, dan kondektur yang ada di lingkungan terminal banyak yang melanggar prinsip kesantunan Leech. Pelanggaran yang paling dominan terjadi pada maksim kebijaksanaan. Wujud ragam bahasa di lingkungan terminal sangat tidak enak didengar, menyakitkan hati. Penulis berharap ada penelitian lanjutan yang lebih spesifik terhadap realisasi ketidaksantunan berbahasa di lingkungan terminal, dengan kajian yang menarik, sampel yang lebih besar, dan teknik analisis yang lebih mendalam untuk mendapatkan hasil kajian yang lebih sempurna.

Penelitian yang dilakukan oleh Novi Trisusanti (2013) yaitu "Realisasi Kesantunan Berbahasa di Lingkungan Pasar Juana Baru Kecamatan Juana Kabupaten Pati Jawa Tengah". Hasil penelitian ini menyimpulkan bahwa realisasi kesantunan berbahasa di lingkungan pasar Juwana Baru menunjukkan bahwa tuturan para calo, pedagang asongan, supir, dan kondektur yang ada di lingkungan pasar Juwana Baru banyak yang melanggar prinsip kesantunan Leech. Pelanggaran yang dominan terjadi pada maksim kebijaksanaan. Wujud ragam bahasa di lingkungan pasar Juwana Baru sangat tidak enak didengar, menyakitkan hati, bicara dengan kepahitan, olok-olok atau sindiran pedas dan mengandung celaan getir.

Pragmatik adalah studi tentang makna yang disampaikan oleh penutur (atau penulis) dan ditafsirkan oleh pendengar (atau pembaca). Sebagai akibatnya studi ini telah banyak berhubungan dengan analisis tentang apa yang dimaksudkan orang dengan tuturan-tuturannya daripada dengan makna terpisah dari kata atau frasa yang digunakan dalam tuturan itu sendiri. Pragmatik adalah studi tentang maksud penutur (Yule, 2006:3). Pragmatik adalah studi tentang makna kontekstual (Yule, 2006:4).

Pendekatan ini juga perlu menyelidiki bagaimana cara pendengar dapat menyimpulkan bahwa apa yang dituturkan agar dapat sampai pada suatu interpretasi makna yang dimaksudkan oleh penutur. Tipe studi ini menggali betapa banyak sesuatu yang tidak dikatakan ternyata menjadi bagian yang disampaikan. Dapat dikatakan bahwa studi ini adalah studi pencarian makna yang tersamar. Pragmatik adalah studi tentang bagaimana agar lebih banyak yang disampaikan daripada yang dituturkan (Yule, 2006:4).

Pandangan ini kemudian menimbulkan pertanyaan apa yang menentukan pilihan antara yang dituturkan dengan yang tidak dituturkan. Jawaban yang mendasar terkait pada gagasan jarak keakraban. Keakraban, baik keakraban fisik, sosial, atau konseptual, menyiratkan adanya pengalaman yang sama. Pada asumsi tentang seberapa dekat atau jauh jarak pendengar, penutur menentukan seberapa banyak kebutuhan yang dituturkan. Pragmatik adalah studi tentang ungkapan dari jarak hubungan (Yule, 2006:4).

Pragmatik adalah studi tentang hubungan antara bentuk-bentuk linguistik dan pemakai bantuk-bentuk itu. Manfaat belajar bahasa melalui pragmatik ialah seseorang dapat bertutur kata tentang makna yang dimaksudkan orang, asumsi mereka, maksud dan tujuan mereka, dan jenis-jenis tindakan (Yule, 2006:5).

Pragmatik mempelajari apa saja yang termasuk struktur bahasa sebagai alat komunikasi antara penutur dan mitra tutur serta sebagai pengacuan tanda-tanda bahasa yang sifatnya ekstralinguistik (Rahardi, 2010:47).

Levinson (dalam Rahardi, 2010:48) mengidentifikasikan pragmatik sebagai studi bahasa yang mempelajari relasi bahasa dengan konteksnya. Konteks yang dimaksud terpramatisasi dan terkondifikasi sehingga tidak dapat dilepaskan dari struktur bahasanya.

Parker (dalam Rahardi, 2010:48-49) menyatakan bahwa pragmatik adalah cabang ilmu bahasa yang memaparkan struktur bahasa secara eksternal. Adapun yang dimaksud dengan hal itu adalah bagaimana satuan lingual tertentu digunakan dalam komunikasi yang sebenarnya. Parker membedakan pragmatik dengan studi tata bahasa yang dianggapnya sebagai studi 
seluk-beluk bahasa secara internal. Menurutnya, studi tata bahasa tidak perlu dikaitkan dengan konteks, sedangkan studi pragmatik muntlak dikaitkan dengan konteks. Berkenaan dengan itu studi tata bahasa dapat dianggap sebagai studi yang bebas konteks (context independents). Sebaliknya, studi pemakaian tata bahasa dalam komunikasi yang sebenarnya muntak dikaitkan dengan konteks yang melatarbelakangi dan mewadahinya. Studi bahasa yang demikian dapat disebut sebagai studi yang terkait konteks (context dependent).

Jacob L. Mey (dalam Rahardi, 2010:49) menjelaskan pragmatik adalah ilmu bahasa yang mempelajari kondisi penggunaan bahasa manusia yang pada dasarnya sangat ditentukan oleh konteks yang mewadahi dan melatarbelakangi bahasa itu. Konteks yang dimaksud mencakup dua hal, yakni konteks yang bersifat sosial (social) dan konteks yang bersifat societal (societal). Konteks sosial (social context) adalah konteks yang timbul sebagai akibat dari munculnya interaksi antaranggota masyarakat dalam suatu masyarakat sosial dan budaya tertentu. Adapun yang dimaksud dengan konteks sociental (societal context) adalah konteks yang faktor penentunya adalah kedudukan (rank) anggota masyarakat dalam institusi-institusi sosial yang ada di dalam masyarakat sosial dan budaya tertentu. Dengan demikian, munculnya konteks societal adalah adanya kekuasaan (power), sedangkan dasar dari munculnya konteks sosietal adalah adanya solidaritas (solidarity).

Pragmatik mengkaji maksud penutur dalam menuturkan sebuah satuan lingual tertentu pada sebuah bahasa. Karena yang dikaji di dalam pragmatik adalah makna, dapat dikatakan bahwa pragmatik dalam banyak hal sejajar dengan semantik yang juga mengkaji makna. Perbedaan antara keduanya adalah bahwa pragmatik mengkaji makna satuan lingual secara eksternal, sedangkan semantik mengkaji makna satuan lingual secara internal. Makna yang dikaji dalam pragmatik bersifat terkait konteks, sedangkan makna yang dikaji dalam semantik bersifat bebas konteks. Makna yang dikaji dalam semantik bersifat diadik, sedangkan makna yang dikaji pragmatik bersifat triadik. Pragmatik mengkaji bentuk bahasa untuk memahami maksud penutur, sedangkan semantik mempelajari bentuk bahasa untuk memahami makna satuan lingual itu (Rahardi, 2010:49-50).

Skala pengukur kesantunan Leech dalam Rahardi (2010:66-68) itu satu per satu dapat dijelaskan lebih lanjut pada bagian berikut:

1. Cost-benefit scale atau skala kerugian dan keuntungan, menunjuk kepada besar kecilnya kerugian dan keuntungan yang diakibatkan oleh sebuah tindak tutur pada sebuah pertuturan. Semakin tuturan tersebut merugikan diri penutur, akan semakin dianggap santunlah tuturan itu. Demikian sebaliknya, semakin tuturan itu menguntungkan diri penutur akan semakin dianggap tidak santunlah tuturan itu. Apabila hal yang demikian itu dilihat dari kacamata si mitra tutur dapat dikatakan bahwa semakin menguntungkan diri mitra tutur, akan semakin dipandang tidak santunlah tuturan itu. Demikian sebaliknya, semakin tuturan itu merugikan diri, si mitra tutur akan dianggap semakin santunlah tuturan itu.

2. Optionality scale atau skala pilihan, menunjuk kepada banyak atau sedikitnya pilihan (options) yang disampaikan si penutur kepada si mitra tutur di dalam kegiatan bertutur. Semakin pertuturan itu memungkinkan penutur atau mitra tutur menentukan pilihan yang banyak dan leluasa, akan dianggap semakin santunlah tuturan itu. Sebaliknya, apabila penuturan itu sama sekali tidak memberikan kemungkinan memilih bagi si penutur dan si mitra tutur, tuturan tersebut akan dianggap tidak santun. Berkaitan dengan pemakaian tuturan imperatif dalam bahasa Indonesia, dapat dikatakan bahwa apabila tuturan imperatif itu menyajikan banyak pilihan tuturan akan menjadi semakin santunlah pemakaian tuturan imperatif itu.

3. Indirectness scale atau skala ketidaklangsungan menunjuk kepada peringkat langsung atau tidak langsungnya maksud sebuah tuturan. Semakin tuturan itu bersifat langsung 
akan dianggap semakin tidak santunlah tuturan itu. Demikian sebaliknya, semakin tidak langsung, maksud sebuah tuturan, akan dianggap semakin santunlah tuturan itu.

4. Authority scale atau skala keotoritasan menunjuk kepada hubungan status sosial antara penutur dan mitra tutur yang terlibat dalam pertuturan. Semakin jauh jarak peringkat sosial (rank rating) antara penutur dan mitra tutur, tuturan yang digunakan akan cenderung menjadi semakin santun. Sebaliknya, semakin dekat jarak peringkat status sosial di antara keduanya, akan cenderung berkuranglah peringkat kesantunan tuturan yang digunakan dalam bertutur itu.

5. Social distance scale atau skala jarak sosial menunjuk kepada peringkat hubungan sosial antara penutur dan mitra tutur yang terlibat dalam sebuah pertuturan. Ada kecenderungan bahwa semakin dekat jarak peringkat sosial di antara keduanya, akan menjadi semakin kurang santunlah tuturan itu. Demikian sebaliknya, semakin jauh jarak peringkat sosial antara penutur dengan mitra tutur, akan semakin santunlah tuturan yang digunakan. Dengan perkataan lain, tingkat keakraban hubungan antara penutur dengan mitra tutur sangat menentukan peringkat kesantunan tuturan yang digunakan dalam bertutur.

\section{METODE}

Penelitian ini menggunakan penelitian deskriptif kualitatif. Objek yang ada pada penelitian ini adalah penyimpangan kesantunan berbahasa pada teks pengumuman karya siswa kelas VII. Data penelitian ini berupa kata dan kalimat yang mengandung penyimpangan kesantunan berbahasa pada teks pengumuman hasil karya siswa kelas VII SMP Muhammadiyah 4 Sambi. Sumber data penelitian ini diambil dari teks pengumuman hasil karya siswa kelas VII SMP Muhammadiyah 4 Sambi. Dalam penelitian ini instrumen utamanya adalah peneliti sendiri, peneliti sebagai human instrument, berfungsi menetapkan fokus penelitian, memilih informan sebagai sumber data, melakukan pengumpulan data, menilai kualitas data, analisis data, menafsirkan data dan membuat kesimpulan atas temuannya. Seorang peneliti harus menyesuaikan diri dengan situasi dan kondisi lapangan untuk keberhasilan mengumpulkan data (Sugiyono, 2012:222).

Teknik pengumpulan data merupakan langkah yang paling strategis dalam penelitian, karena tujuan utama dari penelitian adalah mendapatkan data. Tanpa mengetahui teknik pengumpulan data, maka peneliti tidak akan mendapatkan data yang memenuhi standar data yang ditetapkan (Sugiyono, 2012:224). Teknik pengumpulan data dalam penelitian ini yaitu metode simak dan catat, rekam dan dokumentasi. Metode simak adalah cara yang digunakan untuk memperoleh data dilakukan dengan menyimak penggunaan bahasa (Mahsun, 2013:92). Disebut "metode simak atau penyimakan" karena berupa penyimakan:dilakukan dengan menyimak, yaitu menyimak penggunaan bahasa. Penyimakan atau metode simak itu diwujudkan dengan penyadapan. Peneliti untuk mendapatkan data pertama-tama dengan segenap kecerdikan dan kemauannya harus menyadap pembicaraan (baca: menyadap penggunaan bahasa) seseorang atau beberapa orang. Kegiatan menyadap itu dapat dipandang sebagai teknik dasarnya dan disebut "teknik sadap" (Sudaryanto, 2015:135). Teknik catat adalah teknik lanjutan yang dilakukan ketika menerapkan metode simak dengan teknik lanjutan di atas (Mahsun, 2013:93). Menurut Sugiyono (2012:240) dokumen merupakan catatan peristiwa yang sudah berlalu. Dokumen bisa berbentuk tulisan, gambar, atau karya-karya monumental dari seseorang.

Pada penelitian ini keabsahan data menggunakan teknik triangulasi. Menurut Sugiyono (2012:241) triangulasi diartikan sebagai teknik pengumpulan data yang bersifat menggabungkan dari berbagai teknik pengumpulan data dan sumber data yang telah ada. Jika peneliti melakukan pengumpulan data dengan triangulasi, maka sebenarnya peneliti mengumpulkan yang sekaligus menguji kredibilitas data, yaitu mengecek kredibilitas data dengan berbagai 
teknik pengumpulan data dan berbagai sumber data. Teknik triangulasi dibagi menjadi dua yaitu triangulasi teknik dan triangulasi sumber. Teknik analisis data dalam penelitian ini menggunakan metode padan intralingual. Padan intralingual adalah metode analisis dengan cara menghubungkan-membandingkan unsur-unsur yang bersifat lingual, baik yang terdapat dalam satu bahasa maupun beberapa bahasa yang berbeda.

\section{HASIL DAN PEMBAHASAN}

Hasil penelitian ini menunjukkan bahwa bentuk ketidaksantunan berbahasa pada teks pengumuman karya siswa kelas VII SMP Muhammadiyah 4 Sambi Boyolali, meliputi costbenefit scale atau skala kerugian dan keuntungan, optionality scale atau skala pilihan, indirecness scale atau skala ketidaklangsungan, authority scale atau skala keotoritasan, dan social distance atau skala jarak sosial. Ketidaksantunan berbahasa dalam teks pengumuman karya siswa ditinjau dari skala kerugian dan keuntungan berjumlah dua data. Ketidaksantunan berbahasa dalam teks pengumuman karya siswa ditinjau dari skala ketidaklangsungan berjumlah tujuh data. Ketidaksantunan berbahasa dalam teks pengumuman karya siswa ditinjau dari skala pilihan berjumlah tiga belas data. Ketidaksantunan berbahasa dalam teks pengumuman karya siswa ditinjau dari skala keotoritasan berjumlah satu data. Adapun contoh bentuk yang ditemukan oleh peneliti sebagai berikut.

\section{Skala Kerugian dan Keuntungan}

(1) "saya harapkan siswa-siswi membawa seragam olah raga sendiri" (Seny Nur Hidayati VII B)

Termasuk skala kerugian dan keuntungan menunjuk kepada besar kecilnya kerugian dan keuntungan yang diakibatkan oleh sebuah tindak tutur pada sebuah pertuturan. Semakin tuturan tersebut merugikan diri penutur $(P n)$ akan semakin dianggap santunlah tuturan itu. Demikian sebaliknya, semakin tuturan itu menguntungkan diri penutur $(P n)$ akan semakin dianggap santunlah tuturan itu. Jika dilihat dari kacamata mitra tutur $(M t)$, dapat dikatakan bahwa semakin menguntungkan diri mitra tutur $(M t)$, akan semakin dipandang tidak santunlah tuturan itu. Hal itu dapat dilihat dari penggalan kalimat (1) yaitu "saya harapkan siswasiswi membawa seragam olahraga sendiri". Hal itu menunjukkan bahwa penggalan kalimat tersebut merugikan mitra tutur dan menguntungkan diri sendiri. Hal itu dilihat dari siswa-siswi untuk membawa seragam sendiri saat mengikuti lomba yang diadakan oleh sekolah. Demikian sebaliknya, semakin tuturan itu merugikan diri $(P n)$, si mitra tutur $(M t)$ akan dianggap semakin santunlah tuturan itu. Bentuk kesantunan yang benar terhadap penyimpangan kesantunan berbahasa dalam teks pengumuman karya siswa kelas VII SMP Muhammadiyah 4 Sambi: SMP Muhammadiyah 4 Sambi akan mengadakan lomba untuk memperingati hari kemerdekaan Indonesia yang diikuti oleh semua siswa-siswi. Demi kelancaran lomba, maka siswa diharapkan membawa seragam olaraga sendiri, namun sekolah sudah menyediakan seragam tambahan yang bisa digunakan saat berlangsungnya kegiatan lomba.

(2) "lomba memasak di kampung halaman diharapkan ibu-ibu kampung dukuh datang dan membawa alat masak sendiri” (Puji Lestari VII B)

Termasuk skala kerugian dan keuntungan menunjuk kepada besar kecilnya kerugian dan keuntungan yang diakibatkan oleh sebuah tindak tutur pada sebuah pertuturan. Semakin tuturan tersebut merugikan diri penutur $(P n)$ akan semakin dianggap santunlah tuturan itu. Demikian 
sebaliknya, semakin tuturan itu menguntungkan diri penutur (Pn) akan semakin dianggap santunlah tuturan itu. Jika dilihat dari kacamata mitra tutur dapat dikatakan bahwa semakin menguntungkan diri mitra tutur $(M t)$, akan semakin dipandang tidak santunlah tuturan itu. Hal itu dapat dilihat dari penggalan kalimat (2) yaitu "lomba memasak di kampung halaman diharapkan ibu-ibu kampung dukuh datang dan membawa alat masak sendiri" hal itu menunjukkan bahwa penggalan kalimat tersebut merugikan mitra tutur $(M t)$ dan menguntungkan diri sendiri $(P n)$. Hal itu dilihat dari ibu-ibu kampung dukuh datang dan membawa peralatan memasak sendiri saat mengikuti lomba yang diadakan oleh bapak RT setempat. Demikian sebaliknya, semakin tuturan itu merugikan diri $(P n)$, si mitra tutur $(M t)$ akan dianggap semakin santunlah tuturan itu. Bentuk kesantunan yang benar terhadap penyimpangan kesantunan berbahasa dalam teks pengumuman karya siswa kelas VII SMP Muhammadiyah 4 Sambi:

Kampung Dukuh akan mengadakan perlombaan untuk memperingati hari kemerdekaan Indonesia, salah satu perlombaan yang dapat diikuti oleh ibu-ibu yaitu lomba memasak. Demi kelancaran perlombaan, peserta diharapkan membawa alat memasak sendiri sesuai kebutuhan, akan tetapi panitia juga sudah menyediakan peralatan memasak yang bisa digunakan saat berlangsungnya perlomban.

\section{Skala Ketidaklangsungan}

(3) "mohon partisipasi semua pihak terima kasih" (Vila VII C dan Dina Riska Pratama VII B)

Termasuk skala ketidaklangsungan, menunjuk kepada peringkat langsung atau tidak langsungnya maksud sebuah tuturan. Semakin tuturan itu bersifat langsung akan dianggap semakin tidak santunlah tuturan itu. Hal itu ditunjukkan oleh penggalan kalimat (3) yaitu mohon partisipasi semua pihak terima kasih. Dari penggalan kalimat (3) ditunjukkan bahwa tuturan tersebut bersifat langsung dari penutur $(P n)$ karena semua pihak yang ada di sekolah baik siswa-siswi, guru, maupun pengelola sekolah $(M t)$ wajib mengikuti perlombaan yang diadakan oleh pihak sekolah. Demikian sebaliknya, semakin tidak langsung, maksud sebuah tuturan, akan dianggap semakin santunlah tuturan itu. Kesantunan yang benar terhadap penyimpangan kesantunan berbahasa dalam teks pengumuman karya siswa kelas VII SMP Muhammadiyah 4 Sambi:

Dalam rangka menyukseskan program Boyolali Atlet Renang maka Dinas Pendidikan Kabupaten Boyolali mengadakan lomba renang. Mohon partisipasi dan kesediaan pihakpihak yang bersangkutan demi kelancaran perlombaan. Terima kasih.

(4) "dalam rangka menyesuaikan program jalan sehat, maka warga Samadi akan mengadakan jalan sehat” (Nur Handayani VII C)

Termasuk skala ketidaklangsungan menunjuk kepada peringkat langsung atau tidak langsungnya maksud sebuah tuturan. Semakin tuturan itu bersifat langsung akan dianggap semakin tidak santunlah tuturan itu. Hal itu ditunjukkan oleh penggalan kalimat (4) yaitu dalam rangka menyesuaikan program jalan sehat, maka warga Samadi akan mengadakan jalan sehat. Semua warga wajib mengikuti dengan jalan sehat

Dari penggalan kalimat (4) ditunjukkan bahwa tuturan tersebut bersifat langsung dari penutur $(\mathrm{Pn})$ karena semua warga $(\mathrm{Mt})$ wajib mengikuti perlombaan jalan sehat yang telah diagendakan oleh kelompok KKN (Kuliah Kerja Nyata). Demikian sebaliknya, semakin tidak 
langsung, maksud sebuah tuturan, akan dianggap semakin santunlah tuturan itu. Kesantunan yang benar terhadap penyimpangan kesantunan berbahasa dalam teks pengumuman karya siswa kelas VII SMP Muhammadiyah 4 Sambi:

Dalam rangka menyukseskan program jalan sehat, warga Samadi akan mengadakan lomba jalan sehat. Mohon partisipasi dan kerjasama pihak-pihak yang terkait untuk ikut serta memeriahkan proses perlombaan terima kasih.

\section{Skala Pilihan}

(5) “wajib diikuti seluruh anak-anak dari kelas 1-6" (Ariyanita Warastutik VII A)

Termasuk skala pilihan karena menunjuk kepada banyak atau sedikitnya pilihan (options) yang disampaikan si penutur $(P n)$ kepada si mitra tutur $(M t)$ di dalam kegiatan bertutur. Apabila pertuturan itu sama sekali tidak memberikan kemungkinan memilih bagi si penutur $(P n)$ dan si mitra tutur $(M t)$, tuturan tersebut akan dianggap tidak santun. Berkaitan dengan pemakaian tuturan imperatif itu menyajikan banyak pilihan tuturan akan menjadi semakin santunlah pemakaian tuturan imperatif. Hal itu ditunjukkan oleh penggalan kalimat (5) yaitu wajib diikuti seluruh anak-anak dari kelas 1-6.

Dari penggalan kalimat (5) ditunjukkan bahwa tuturan tersebut termasuk dalam skala pilihan karena mewajibkan anak-anak untuk mengikuti perlombaan yang telah diselenggarakan oleh karang taruna Desa Tempusari. Demikian sebaliknya, semakin pertuturan itu memungkinkan penutur $(P n)$ atau mitra tutur $(M t)$ menentukan pilihan yang banyak dan leluasa, akan dianggap semakin santunlah tuturan itu. Bentuk kesantunan yang benar terhadap penyimpangan kesantunan berbahasa dalam teks pengumuman karya siswa kelas VII SMP Muhammadiyah 4 Sambi:

Dalam rangka memperingati Hut RI ke 70, karang taruna Desa Tempusari mengadakan berbagai macam perlombaan yang diikuti oleh warga setempat baik anak-anak, ibu-ibu maupun bapak-bapak. Jenis lomba dapat ditentukan sendiri sesuai dengan kesukaan. Waktu dan tempat sudah tertera dalam jadwal perlombaan. Mohon partisipasi dan kerja sama warga desa. Sekian dan terima kasih.

(6) "Dinas Pendidikan kabupaten Boyolali mengadakan lomba renang yang wajib diikuti seluruh SMP se-kabupaten Boyolali” (Vila VII C)

Termasuk skala pilihan karena menunjuk kepada banyak atau sedikitnya pilihan (options) yang disampaikan si penutur $(P n)$ kepada si mitra tutur $(M t)$ di dalam kegiatan bertutur. Apabila pertuturan itu sama sekali tidak memberikan kemungkinan memilih bagi si penutur $(P n)$ dan si mitra tutur $(M t)$, tuturan tersebut akan dianggap tidak santun. Berkaitan dengan pemakaian tuturan imperatif itu menyajikan banyak pilihan tuturan akan menjadi semakin santunlah pemakaian tuturan imperatif. Hal itu ditunjukkan oleh penggalan kalimat (6) yaitu Dinas Pendidikan Kabupaten Boyolali mengadakan lomba renang yang wajib diikuti seluruh SMP se-Kabupaten Boyolali

Dari penggalan kalimat (6) ditunjukkan bahwa tuturan tersebut termasuk dalam skala pilihan karena mewajibkan seluruh Sekolah Menengah Pertama (SMP) se-Kabupaten Boyolali untuk mengikuti perlombaan renang yang diadakan oleh Dinas Pendidikan Kabupaten Boyolali sehingga mau atau tidak mau, sekolah harus mengikuti perlombaan yang telah diagendakan. 
Demikian sebaliknya, semakin pertuturan itu memungkinkan penutur $(P n)$ atau mitra tutur $(M t)$ menentukan pilihan yang banyak dan leluasa, akan dianggap semakin santunlah tuturan itu. Kesantunan yang benar terhadap penyimpangan kesantunan berbahasa dalam teks pengumuman karya siswa kelas VII SMP Muhammadiyah 4 Sambi:

Dalam rangka menyukseskan program Boyolali Atlet Renang, Dinas Pendidikan Kabupaten Boyolali mengadakan perlombaan renang yang diikuti oleh pihak sekolah Sekolah Menengah Pertama (SMP) se-Kabupaten Boyolali. Mohon partisipasi semua pihak yang bersangkutan untuk ikut memeriahkan jalannya perlombaan. Sekian dan terima kasih.

\section{Skala Keotoritasan}

\section{(7) “sekian pengumuman saya" (D Nur H VII B)}

Termasuk skala keotoritasan karena menunjuk kepada hubungan status sosial antara penutur $(P n)$ dan mitra tutur $(M t)$ yang terlibat dalam penuturan. Semakin dekat jarak peringkat status sosial di antara keduanya yaitu penutur $(P n)$ dengan mitra tutur $(M t)$, akan cenderung berkuranglah peringkat kesantunan tuturan yang digunakan dalam bertutur. Hal itu ditunjukkan oleh penggalan kalimat (7) yaitu sekian pengumuman saya.

Dari penggalan kalimat (7) ditunjukkan bahwa tuturan tersebut termasuk dalam skala keotoritasan karena tuturan tersebut tidak diikuti dengan ucapan terima kasih kepada pihakpihak yang bersangkutan. Pengumuman tersebut tidak hanya dilihat oleh siswa-siswi, akan tetapi juga dilihat oleh pihak sekolah yang lainnya sehingga bahasa yang digunakan juga harus santun.

Demikian sebaliknya, semakin jauh jarak peringkat sosial (rank rating) antara penutur $(P n)$ dengan mitra tutur $(M t)$, tuturan yang digunakan akan cenderung menjadi semakin santun.

Kesantunan yang benar terhadap penyimpangan kesantunan berbahasa dalam teks pengumuman karya siswa kelas VII SMP Muhammadiyah 4 Sambi yaitu:

Dalam rangka memperingati Hut RI, SMP Muhammadiyah 4 Sambi akan mengadakan beberapa perlombaan seperti voli, kelereng, kebersihan kelas, mading, dan masih banyak lagi. Siswa-siswi diharapkan dapat ikut memeriahkan proses perlombaan dengan mengikuti perlombaan sesuai jadwal yang telah ditentukan. Atas perhatian dan partisipasi semua pihak kami ucapkan terima kasih.

\section{SIMPULAN}

Hasil penelitian ini menunjukkan bahwa bentuk ketidaksantunan berbahasa pada teks pengumuman karya siswa kelas VII SMP Muhammadiyah 4 Sambi Boyolali, meliputi cost-benefit scale atau skala kerugian dan keuntungan, optionality scale atau skala pilihan, indirecness scale atau skala ketidaklangsungan, authority scale atau skala keotoritasan, dan social distance atau skala jarak sosial.

Ketidaksantunan berbahasa dalam teks pengumuman karya siswa ditinjau dari skala kerugian dan keuntungan berjumlah dua data. Ketidaksantunan berbahasa dalam teks pengumuman karya siswa ditinjau dari skala ketidaklangsungan berjumlah tujuh data. Ketidaksantunan berbahasa dalam teks pengumuman karya siswa ditinjau dari skala pilihan berjumlah tiga belas data. Ketidaksantunan berbahasa dalam teks pengumuman karya siswa ditinjau dari skala keotoritasan berjumlah satu data. 
Teks pengumuman pada dasarnya disampaikan secara singkat, padat, dan jelas. Apabila ditinjau dari skala kesantunan di bidang pragmatik, sebenarnya penggunaan bahasa yang singkat menunjukkan bentuk ketidaksantunan. Hasil penelitian ini mendeskripsikan bentuk ketidaksantunan berbahasa yang digunakan siswa untuk membedakan bentuk kesantunan berbahasa maupun ketidaksantunan berbahasa.

\section{DAFTAR PUSTAKA}

Mahsun. 2013. Metode Penelitian Bahasa. Jakarta: PT Raja Grafindo Persada.

Markhamah, dkk. 2013. Analisis Kesalahan dan Kesantunan Berbahasa. Surakarta: Muhammadiyah University Press.

Rahardi, Kunjana. 2010. Pragmatik: Kesantunan Imperatif Bahasa Indonesia. Jakarta: Erlangga.

Setiawan, Budi. 2011. "Realisasi Ketidaksantunan Berbahasa di Lingkungan Terminal Kartasura”. Skripsi. Surakarta: Universitas Muhammadiyah Surakarta.

Sugiyono. 2012. Metode Penelitian Kuantitatif, Kualitatif dan $R \& D$. Bandung: Alfabeta.

Trisusanti, Novi. 2013. "Realisasi Kesantunan Berbahasa di Lingkungan Pasar Juana Baru Kecamatan Juana kabupeten Pati Jawa Tengah”. Skripsi. Surakarta: Universitas Muhammadiyah Surakarta.

Yule, George. 2006. Pragmatik. Yogyakarta: Pustaka Pelajar. 